\title{
Öğretmen Adayları Tarafından Tasarlanan Ders Planlarında Sosyo-Bilimsel Konular ve Girişimcilik: Bir Karma Yöntem Araştırması
}

\section{Bülent Aydoğdu ${ }^{1} \quad$ Tuğba Selanik Ay ${ }^{2} \quad$ Nil Duban ${ }^{3}$}

\section{Type/Tür:}

Research/Araştırma

Received/Geliş Tarihi:

January 13/ 13 Ocak 2020

Accepted/Kabul Tarihi:

November 18/ 18 Kasim 2020

Page numbers/Sayfa No:

1107-1132

Corresponding

Author/İletişimden Sorumlu

Yazar: baydogdu@aku.edu.tr

\section{$\checkmark$ iThenticate $^{\circ}$}

This paper was checked for plagiarism using iThenticate during the preview process and before publication. / $\mathrm{Bu}$ çalışma ön inceleme sürecinde ve yayımlanmadan önce iThenticate yazılımı ile taranmıştır.

\section{Copyright $@ 2017$ by} Cumhuriyet University, Faculty of Education. All rights reserved.

\section{Öz}

$\mathrm{Bu}$ araştırmanın amacı, sınıf öğretmeni adaylarının sosyo-bilimsel konulara yönelik tutumlarını ve girişimcilik düzeylerini belirleyerek aralarındaki ilişkiyi ortaya koymak ve ders plânlarında sosyo-bilimsel konulara ve girişimciliğe nasıl yer verdiklerini ortaya çıkarmaktır. Bu araştırma, bir karma yöntem araştırmasıdır. Araştırmanın katılımcılarını, üçüncü sınıflarda öğrenim gören 88 sınıf öğretmeni adayı oluşturmaktadır. Katılımcılar, amaçsal örnekleme yöntemlerinden ölçüt örnekleme yöntemine göre seçilmiştir. Öğretmen adaylarının seçiminde aranan ölçüt ise "Fen ve Teknoloji Öğretimi I-II" ve "Sosyal Bilgiler Öğretimi" derslerini almış olmalarıdır. Veri toplama aracı olarak "Sosyo-bilimsel Konulara Yönelik Tutum Ölçeği" ve "Üniversite Öğrencilerine Yönelik Girişimcilik Ölçeği” ayrıca doküman olarak "Ders Planları" kullanılmıştır. Nitel veriler, doküman analizine tabi tutulurken nicel veriler istatistiksel paket programı yoluyla analiz edilmiştir. Nicel verilerden elde edilen sonuçlar, sınıf öğretmen adaylarının sosyo-bilimsel konulara yönelik ortalama tutum puanlarının "sık sık" düzeyinde olduğu görülmüştür. Benzer şekilde, girişimcilik ortalama puanların "katıliyorum" düzeyinde olduğu görülmüştür. Ayrıca, sınıf öğretmeni adaylarının sosyo-bilimsel konulara yönelik tutumları ile girişimcilikleri arasında orta düzeyde pozitif bir ilişkinin olduğu görülmüştür. Bunlara ek olarak, nitel verilerden elde edilen sonuçlara göre öğretmen adaylarının hazırladıkları ders planları incelendiğinde girişimciliğin tüm boyutlarına yer verdikleri; sosyo-bilimsel konuların ise bir kısmına değinip bir kısmına hiç değinmedikleri belirlenmiştir. Hem fen bilimleri hem de sosyal bilgiler dersi öğretim programlarına göre hazırlanan ders planlarında ortak olarak yer verilen sosyo- bilimsel konular, kirlilik, beslenme ve obezite ile doğal kaynakları koruma şeklinde belirlenmiştir.

Anahtar Kelimeler: Öğretmen adayı, ders planı, fen eğitimi, girişimcilik, sosyo-bilimsel

\section{Suggested APA Citation/Önerilen APA Atıf Biçimi:}

Aydoğdu, B., Selanik Ay, T. \& Duban, N. (2020). Öğretmen adayları tarafından tasarlanan ders planlarında sosyo-bilimsel konular ve girişimcilik: Bir karma yöntem araştırması. Cumhuriyet International Journal of Education, 9(4), 1107-1132. http:/ / dx.doi.org/10.30703/cije.674350

\footnotetext{
${ }^{1}$ Doç. Dr., Afyon Kocatepe Üniversitesi, Fen Bilimleri Eğitimi Bölümü, Afyonkarahisar/Türkiye Assoc.Prof.Dr., Afyon Kocatepe University, Department of Science Education ,Afyon/Turkey e-mail: baydogdu@aku.edu.tr ORCID ID: https:/ / orcid.org/0000-0003-1989-6081

2 Doç. Dr., Afyon Kocatepe Üniversitesi, Temel Eğitim Bölümü, Afyonkarahisar/Türkiye Assoc.Prof.Dr., Afyon Kocatepe University, Department of Primary Education, Afyon/Turkey e-mail: tsay@aku.edu.tr ORCID ID: https:// orcid.org/0000-0003-1368-052X

3 Prof. Dr., Afyon Kocatepe Üniversitesi, İlköğretim Bölümü, Afyonkarahisar/Türkiye Prof.Dr., Afyon Kocatepe University, Department of Primary Education, Afyon/Turkey e-mail: nily@aku.edu.tr ORCID ID: https:// orcid.org/0000-0002-8851-0114
} 


\title{
Socio-Scientific Issues and Entrepreneurship in Interdisciplinary Lesson Plans Designed by Pre-Service Teachers: A Mixed Method Research
}

\begin{abstract}
The aim of this study is to determine the attitudes of pre-service primary school teachers towards socio-scientific issues and their level of entrepreneurship and to reveal how they place socio-scientific issues and entrepreneurship in their lesson plans. In current study, mixed method research was used. The participants of the study consisted of 88 pre-service primary school teachers. Participants were selected according to the criterion sampling method. The criterion was to take the courses "Science and Technology Teaching I-II" and "Social Studies Teaching". "Attitude Scale for Socio-Scientific Issues" and "Entrepreneurship Scale for University Students" were used as data collection tools and "Lesson Plans" were used as documents. While qualitative data were subjected to document analysis, quantitative data were analyzed through a statistical package program. According to the results obtained from the quantitative data, it was observed that the average attitude scores of the pre-service primary school teachers towards socio-scientific issues were "often". Similarly, the average scores of entrepreneurship were "agree". In addition, there was a moderate positive relationship between the attitudes of pre-service primary school teachers towards socio-scientific issues and their entrepreneurship. In addition, according to the results obtained from the qualitative data, it was observed that the lesson plans prepared by the pre-service primary school teachers included all the dimensions of entrepreneurship; and some of the socio-scientific issues were not mentioned. The socio-scientific issues, which are included in the lesson plans prepared according to both science and social studies curriculum, are determined as pollution, nutrition and obesity and conservation of natural resources.
\end{abstract}

Keywords: Pre-service teachers, lesson plan, science education,, entrepreneurship. socio-scientific

\section{Giriş}

Bilimin toplumun ihtiyaçlarına yönelik olarak değiştiği, benzer şekilde bilimsel gelişmelerin ve değişimlerin de toplumların şekillenmesi üzerine etkili olduğu bilinmektedir. Bu bağlamda bilim ve toplum kavramlarının birbirleri ile sürekli olarak bir ilişki içerisinde olması gerektiği söylenebilir (Sadler ve Zeidler, 2005: 113). Özellikle bilimsel alanda günümüzde yaşanan büyük ve hızl değişimler, bu süreçlerin içerisinde sosyo-bilimsel konuların sıklıkla karşımıza çıkmasını da kaçınılmaz hale getirmektedir (Sadler, 2004: 529). Eastwood Sadler, Zeidler, Lewis, Amiri ve Applebaum (2012)'a göre sosyo-bilimsel konular fen temelli konu içerikleri ile ilişkili ve sosyal açıdan da bir anlam ve önem içeren kavramlar olarak nitelenebilir. Sosyo-bilimsel konular, üzerinde kolayca karar verilemeyen, farklı bakış açılarıyla ele alınan tartışmalı konulardır. Sosyo-bilimsel konulara; ozon tabakasının incelmesi, genetik kopyalama, sağlıkla ilgili sorunlar, hormonlu gıdalar ya da genetiği değiştirilmiş gıdalar (GDO), nükleer silahlanma, nükleer enerji kullanımı (santraller), teknolojik icatlar, küresel ısınma, toprak kullanımı, obezite, doğa katliamı, kirlilik, çocuk istismarı, aile içi sorunlar, hayvanlara şiddet, etnik ayrımcılık vb. sorunlar örnek olarak verilebilir (Türkmen, Pekmez, Sağlam, 2017). Sosyo-bilimsel konular evrensel, ulusal ve yerel kapsamda incelenebilmektedir. Örneğin küresel ısınma evrensel bir konuyken, Sinop'ta, Mersin'de (Akkuyu) ve Kırklareli'nde (İğne Ada) kurulması planlanan nükleer santraller, Karadeniz'deki Yeşil Yol Projesi, Kaçak Elektrik Kullanımları gibi konular ulusal ve yerel bağlamda 
incelenebilecek sosyo-bilimsel konulardır (Evren Yapıcıŏlu ve Kaptan, 2017; Topçu, Muğaloğlu ve Güven, 2014).

Lee, Abd-El-Khalick ve Choi (2006), sosyo-bilimsel konuların tanımını sosyal çelişkiler üzerinden yapmaktadırlar. Ahlaki ve etik boyutlar içeren sosyo-bilimsel konuların aynı zamanda insan hayatına etkileri olacağını da belirtmektedirler. Hodson (2006) sosyo-bilimsel konuların, ekonomik, politik, dini, etik ve çevresel olmak üzere pek çok boyutu olduğunu ifade etmektedir. Bu bağlamda düşünüldüğünde sosyo-bilimsel konular, bilimsel bilgi noktasında, yöntemsel ya da teknolojik boyutlarda, ahlâki ve etik açıdan karmaşık hale gelmekte ve toplumlar tarafından tartışılmaktadır (Sadler ve Donnelly, 2006). Molinatti, Girault ve Hammond (2010) ise sosyo-bilimsel konuları bireylerin sağlık, çevre, tekno bilimsel yenilikler gibi alanlarda karşılaştıkları sosyal ikilemleri çözme ve karar verme süreçlerinde bilimden yararlanmaları biçiminde tanımlamaktadırlar.

Bilimsel dayanaklı ahlâki ve etik durumlar içeren sosyo-bilimsel konuların öğretiminde, argümantasyona başvurma veya problem senaryoları aracıllğıyla öğretim sürecinde; öğrencilerin ilgisini çekecek, bilimsel niteliğe sahip etik ve ahlâki durumları içeren senaryolar seçilerek, bu senaryolar üzerinden öğrenci tartışmaları yönlendirilerek, öğrencilerin bu konular hakkında derinlemesine araştırma yapıp bilgi sahibi olması sağlanabilir. Ayrıca sosyo-bilimsel konuların ikilem kartları aracılığıyla ele alınmasının öğrenme sürecinde etkili olacağı vurgulanmaktadır. İkilem kartları öğrencilerin akranları ile karşılıklı olarak sorgulama sürecine girecekleri ve kararlarını yeniden değerlendirmelerinin yanı sıra, fikirler, inançlar ve eylemlerini açıkça söylemelerini sağlayacağı için onları cesaretlendireceği belirtilmektedir (Evren Yapıcıoğlu ve Kaptan, 2018; Evren Yapıcıŏglu ve Kaptan, 2017)

Sosyo-bilimsel konuları tartı̧abilmek ve çözümleyebilmek, fen okuryazarlığının bileşenlerinin tamamlayıcısıdır. Sosyo-bilimsel konular yoluyla fen okuryazarlığı ile arasındaki ilişki incelendiğinde, fenle ilgili günlük yaşamdan alınan konuları araç olarak kullanmanın, öğrencilerin öğrenme heyecanı ve isteğini arttıracağı belirlenmiştir (Sadler ve Zeidler, 2009). Bu noktadan hareketle, öğrencileri fen okuryazarı bireyler olarak yetiştirebilmek için atılacak adımlardan biri öğretmenlerin bu konulara değinmeleri ve çeşitli etkinliklerle bu konuların tartışılmasını sağlayarak farkındalık oluşturmalarıdır. Öğretmenleri bu konuda desteklemek ve işini kolaylaştırmak için öğretim programlarında sosyo-bilimsel konulara yer verilmesi de önem taşımaktadır. Sosyo-bilimsel konularla karşılaşan bireylerin fayda ve risk analizlerini yapabilmesi, konuyla ilgili karar verebilmesi, düşüncelerini kanıt ve muhakemelerle savunabilmesi beklenmektedir. Bireylerin bu becerileri kazanabilmesi için sosyo-bilimsel konuların öğrenme-öğretme sürecine farklı etkinliklerle entegre edilmesi gerekmektedir (Topçu ve Atabey, 2017). Bu entegrasyonun etkili biçimde gerçekleştirilebilmesi için bireylerin çevrelerindeki bilimsel gelişmelere ve durumlara karşı duyarlı olmaları, fırsatları fark etmeleri, yenilikçi ve yaratıcı bireyler olmaları gerekmektedir. Bu da ancak bireylerin girişimcilik becerisine sahip olmaları ile mümkün olabilir. Girişimciliğin özellikleri ve girişimci bireyin sahip olması gereken nitelikler ele alındığında girişimcilik türleri de kendiliğinden ortaya çıkmakta ve alan yazında farklı biçimlerde vurguları yapılmaktadır. Örneğin girişimciliğin, sosyal girişimcilik, çevreci girişimcilik, dijital 
girişimcilik, orjinal girişimcilik, iç girişimcilik gibi birçok türü olmakla birlikte bu araştırma kapsamında sosyo-bilimsel konularla ilişkilendirilebilecek olanlar sosyal ve çevreci girişimciliktir. Sosyal girişimcilik, girişimcilerin faaliyetlerini doğrudan toplumsal değer yaratma hedefine bağlı olacak şekilde uyarladığı alan (Saifan, 2012); çevreci girişimci, toplumsal sorunlar için örnek çözümler sunan, iş yaşamı ve çevresel farkındalığı bütüncül bir bakış açısı ile ele alan, girişimlerinde çevreciliği ön planda tutan ve çeşitli girişimlerle çevreci faaliyetlere katkı sağlayan girişimcilik türüdür (O'Neil ve Gibbs, 2016). Bu bağlamda, sosyo-bilimsel konular ile ilgili pek çok boyutun (çevre kirliliği, sosyal sorunlar...vb) girişimcilik becerisi ile ilişkili olduğu söylenebilir.

Ülkemizde sosyo-bilimsel konular 2005 y1lı Fen ve Teknoloji Dersi Öğretim Programı'nda "Fen-Teknoloji-Toplum-Çevre" öğrenme alanı bağlamında yer alırken, 2013 yılı Fen Bilimleri Dersi Öğretim Programı'nda “Fen-Teknoloji-Toplum-Çevre" öğrenme alanının alt alanı olarak doğrudan yer almış, 2017'de güncellenen Fen Bilimleri Dersi Öğretim Programı́nın amaçları arasında sosyo-bilimsel konulardan "Sosyo-bilimsel konuları kullanarak muhakeme yeteneği, bilimsel düşünme alışkanlıkları ve karar verme becerileri geliştirmek" olarak söz edilmiştir. Ancak 2018 yılında bir öğrenme alanı içerisinde alt alan olarak değil yalnızca Fen Bilimleri Dersi Öğretim Programı'nın temel amaçları içinde “Sosyo-bilimsel konuları kullanarak muhakeme yeteneği, bilimsel düşünme alışkanlıkları ve karar verme becerileri geliştirmek" biçiminde değinilmiştir. Girişimcilik becerisi ise "inisiyatif alma ve girişimcilik" biçiminde, 2018 yılı Fen Bilimleri ve Sosyal Bilgiler dersi öğretim programlarında yer alan sekiz anahtar yetkinlikten biri olarak karşımıza çıkmaktadır (MEB, 2005; MEB, 2013; MEB, 2018).

Yapılan araştırmalarda, sosyo-bilimsel konulara ve öğretimine yönelik öğretmen ve öğretmen adaylarının bilgi düzeylerinin istenen seviyede olmadığ1 ve öğretmenlerin derslerinde bu tür konulara çok fazla yer vermedikleri ya da plânsız tartışmalarla dersi geçiştirdikleri ortaya çıkmıştır. (Topçu, Muğaloğlu ve Güven, 2014; Sönmez, 2015; Evren Yapıcığlu ve Kaptan, 2018; Tezel ve Günister, 2018). Öğretmen ve öğretmen adayları ile yürütülen sosyo- bilimsel konular ile girişimciliği birlikte ele alan ya da ikisi arasındaki ilişkiyi inceleyen bir araştırmaya rastlanmamıştır. Bu çalışma, karma yöntem araştırması biçiminde tasarlanıp sosyobilimsel konular ile girişimciliği birlikte ele alması ve öğretmen adaylarının ders plânlarında sosyo- bilimsel konulara ve girişimciliğe nasıl yer verildiğinin görülmesi açısından önemlidir. Bu noktadan hareketle araştırmanın amacı, sınıf öğretmeni adaylarının sosyo-bilimsel konulara yönelik tutumlarını ve girişimcilik düzeylerini belirleyerek aralarındaki ilişkiyi ortaya koymak ve ders plânlarında sosyo- bilimsel konulara ve girişimciliğe nasıl yer verdiklerini ortaya çıkarmaktır. Bu genel amaç doğrultusunda aşağıdaki sorulara yanıt aranmıştır:

1. Sınıf öğretmeni adaylarının sosyo--bilimsel konulara yönelik tutumları hangi düzeydedir?

2. Sinıf öğretmeni adaylarının girişimcilik düzeyleri nasıldır?

3. Sınıf öğretmeni adaylarının sosyo--bilimsel konulara yönelik tutumları ile girişimcilik düzeyleri arasında nasıl bir ilişki vardır?

4. Sınıf öğretmeni adayları ders planlarında sosyo--bilimsel konulara nasıl yer vermişlerdir? 
5. Sınıf öğretmeni adayları ders planlarında girişimciliğe nasıl yer vermişlerdir?

\section{Yöntem}

$\mathrm{Bu}$ bölümde, çalışma grubuna, araştırma desenine, veri toplama araçlarına, veri toplama sürecine ve verilerin analizine yer verilmiştir.

\section{Çalışma Grubu}

Araştırmanın çalışma grubunu, üçüncü sınıflarda öğrenim gören 88 sinıf öğretmeni adayı oluşturmaktadır. Katılımcılar, amaçsal örnekleme yöntemlerinden ölçüt örnekleme yöntemine göre seçilmiştir. Öğretmen adaylarının seçiminde aranan ölçüt ise "Fen ve Teknoloji Öğretimi I-II" ve "Sosyal Bilgiler Öğretimi" derslerini almış olmaktır.

\section{Araştırma Deseni}

$\mathrm{Bu}$ araştırmada karma yöntem araştırmaları kapsamında yakınsayan paralel desen kullanılmıştır. Yakınsayan paralel desenin amacı aynı konu üzerinde farklı fakat birbirini tamamlayıcı veri toplamaktır. Bu desen araştırmanın nicel ve nitel aşamalarına ilişkin eş zamanlı olarak verilerin toplanmasıyla yürütülür. Yakınsayan paralel desen nicel ve nitel yöntemlere eşit öncelik verir, çözümleme sırasında bu aşamaları birbirinden ayrı tutar ve daha sonra genel yorumlama yaparken sonuçları birleştirir (Creswell ve Plano, 2014). Bu araştırma sürecinde de veri toplama araçları (ölçekler) uygulanırken eş zamanlı olarak öğretmen adayları ders plânlarını geliştirmişlerdir.

\section{Veri Toplama Araçları}

Veri toplama aracı olarak; "Sosyo-bilimsel Konulara Yönelik Tutum Ölçeği (SKYTÖ)”, “Üniversite Öğrencilerine Yönelik Girişimcilik Ölçeği (ÜÖYGÖ)” ve “Dokümanlar (5E Öğrenme Halkası Modeline Göre Hazırlanan Ders Planları)" kullanilmıştır.

Sosyo-bilimsel konulara yönelik tutum ölçeği (SKYTÖ). SKYTÖ, Topçu (2010) tarafından geliştirilmiştir. SKYTÖ, üç alt boyuttan ve 30 maddeden oluşan beşli likert tipinde bir ölçektir. "Sosyo-bilimsel konuların yarar ve önemi" alt boyutunda Cronbach Alpha iç güvenirlik katsayısı 0.90, "Sosyo-bilimsel konulardan hoşlanma" alt boyutunda 0.81 ve son olarak "Sosyo-bilimsel konulara yönelik kayg1" alt boyutunda 0.70 olarak verilmiştir (Topçu, 2010). Benzer şekilde mevcut çalışmada, "Sosyo-bilimsel konuların yarar ve önemi" alt boyutunda Cronbach Alpha iç güvenirlik katsayısı 0.90, "Sosyo-bilimsel konulardan hoşlanma" alt boyutunda 0.78 ve "Sosyo-bilimsel konulara yönelik kayg1" alt boyutunda 0.62 olarak, ölçeğin tümüne ilişkin ise 0.90 olarak bulunmuştur.

Üniversite öğrencilerine yönelik girişimcilik ölçeği (ÜÖYGÖ). ÜÖYGÖ, Yılmaz ve Sümbül (2009) tarafından geliştirilmiştir. ÜÖYGÖ, tek faktörlü ve 36 maddeden oluşan beşli likert tipinde bir ölçektir. ÜÖYGÖ'nün güvenirlik katsayısı ise 0.90 olarak verilmiştir (Yılmaz ve Sümbül, 2009). Mevcut çalışmada ise güvenirlik katsayısı 0.94 olarak bulunmuştur.

Dokümanlar (5E öğrenme halkası modeline göre hazırlanan ders planları). $\mathrm{Bu}$ araştırmada sınıf öğretmenleri tarafından tasarlanan ders plânları araştırmanın dokümanları olarak ele alınmıştır. Hangi dokümanların önemli olduğu ve veri 
kaynağı olarak kullanılabileceği araştırma problemleri ile yakından ilgilidir. Örneğin eğitimle ilgili bir araştırmada; ders kitapları, program yönergeleri, öğrenci kayıtları, toplantı tutanakları, ders ve ünite planları dokümanlar olarak ele alınabilmektedir (Yıldırım ve Şimşek, 2013). Bu bağlamda, sınıf öğretmen adaylarından "Fen ve Teknoloji Öğretimi I-II" ve "Sosyal Bilgiler Öğretimi" derslerini aldıktan sonra hem sosyo-bilimsel konuları hem de girişimciliği içeren 5E öğrenme halkası modeline göre her ders için ayrı ders plânları tasarlamaları istenmiştir.

\section{Veri Toplama Süreci}

Sınıf öğretmenliği lisans programı 3. sınıf düzeyinde öğretmen adayları, güz ve bahar eğitim ve öğretim dönemleri sürecinde "Fen ve Teknoloji Öğretimi I" ve "Fen ve Teknoloji Öğretimi II" dersi kapsamında öğretmen adayları sosyo-bilimsel konuları, fen bilimleri öğretim programı ve 5E öğrenme halkası modeline göre ders plânı hazırlamayı ve uygulamayı; bahar döneminde ise "Sosyal Bilgiler Öğretimi" dersi kapsamında Sosyal Bilgiler Öğretim Programından seçtikleri kazanımları girişimcilikle ile ilişkilendirerek ders planları hazırlamayı öğrenmişlerdir. Bununla birlikte Fen Bilimleri ve Sosyal bilgiler derslerinin öğretim programlarında sekiz anahtar yetkinlikten biri olan "İnisiyatif alma ve girişimcilik" boyutu ve bu boyutla ilgili derslerde yapılan tartışmalar öğretmen adaylarının bu konudaki farkındalıklarının artmasını sağlamıştır. "Fen ve Teknoloji Öğretimi II" ve "Sosyal Bilgiler Öğretimi" derslerinin son haftasında öğretmen adaylarından hem sosyobilimsel konuları hem de girişimcilik konularını içeren 5E öğrenme halkası modeline göre her bir ders için ayrı plânlar hazırlamaları istenmiştir. Bu plânlar hazırlanırken öğretmen adaylarına her iki dersin (fen bilimleri ve sosyal bilgiler dersi) öğretim programından kazanımlar alarak çalışmaları gerektiği belirtilmiştir.

\section{Verilerin Analizi}

Sınıf öğretmeni adayları tarafından hazırlanan 88 adet ders plânı, alan yazına dayalı olarak hazırlanan ölçütler takımı kullanılarak doküman analizine tabi tutulmuştur. Doküman incelemesi, araştırılması hedeflenen olgu ya da olgular hakkında bilgi içeren yazılı materyallerin analizini kapsamaktadır (McMillan ve Schumacher, 2010; Merriam, 1998). Öğretmen adayları tarafından hazırlanan ders planları önce numaralandirmış [Plan 1(P1), Plan 2 (P2)...], sonra da tek tek önceden belirlenmiş olan alt temalara göre incelenmiştir. Bu temalar alan yazın taraması yapılarak sosyobilimsel konulara ve girişimciliğe ilişkin alt boyutların ortaya çıkarılıp listelenmesi ile oluşturulmuştur. Sosyo-bilimsel konulara ilişkin temalar; ozon tabakası, atıkları depolama, organ bağışı, canlı çeşitliliğini koruma, çevresel eylemler, doğal kaynakları koruma, beslenme önerileri (obezite), yoksulluk, kirlilik, genetik ve üreme teknolojileri, embriyo seçimi, enerjinin korunumu, GDO, klonlama, nükleer enerji, salgın hastalıklar, biyoteknoloji, uzay araştırmaları, küresel ısınma, alternatif enerji kaynakları (Türkmen, Pekmez ve Sağlam, 2017; Özden, 2016; Öztürk ve Leblebicioğlu, 2015) şeklindedir. Girişimcilik konularına ilişkin temalar ise; proaktiflik (öncü olma), fırsatları fark etme, yenilikçilik ve yaratıcılık (iş fikri belirleme), kaynakları etkili kullanma, maliyet analizi, risk alma, sorumluluk alma, yönetsel yetkinlik, planlama, ikna ve iletişim, pazarlama stratejileri, rekabetçi düşünme, farklı alanlara uyarlama ve değerlendirme (A ğca ve Kurt, 2007; KılıçKırılmaz, 2014; Topkaya, 2013; Şen ve Aslan, 2017; Çavuş ve Pekkan, 2017) 
şeklindedir. Doküman analizinden elde edilen bulgular ders plânlarından kesitler eklenerek sunulmuştur. Araştırmanın nitel boyutunda güvenirliğini sağlamak amacıyla, verilerin yüzde yirmisi araştırmacılar tarafından ayrı ayrı incelenmiş ve uyuşum yüzdesini hesaplamak için Miles ve. Huberman (1994) tarafından önerilen Görüş birliği/(Görüş birliği+Görüş ayrılığı) X 100 formülü kullanılmıştır. Bu hesaplama sonucunda uyuşum yüzdesi 0.85 olarak bulunmuştur. Nicel veriler, bilgisayar ortamında istatistiksel paket programı kullanılarak analiz edilmiştir. Bu kapsamda nicel veriler, pearson momentler çarpımı korelasyonu ile aritmetik ortalama, standart sapma gibi betimsel istatistik hesaplamaları yapılarak detaylı bir şekilde analiz edilmiştir.

\section{Bulgular}

Araştırmanın bu bölümünde öğretmen adaylarından elde edilen bulgular, nicel ve nitel bulgular bağlamında sunulmuş; sonrasında ise elde edilen bulguların birlikte ele alınması ile yorumlanmıştır.

\section{Sosyo-bilimsel Konulara Yönelik Tutum Ölçeği (SKYTÖ) ve Üniversite Öğrencilerine Yönelik Girişimcilik Ölçeği (ÜÖYGÖ)'den Elde Edilen Nicel Bulgular}

Tablo 1'de sınıf öğretmeni adaylarının "Sosyo-bilimsel Konulara Yönelik Tutum Ölçeği" ve "Üniversite Öğrencilerine Yönelik Girişimcilik Ölçeği”nden aldıkları ortalama puanlar verilmiştir.

Tablo 1.

Sinıf Öğretmeni Adaylarının "Sosyo-bilimsel Konulara Yönelik Tutum Ölçeği-SKYTÖ" ve "Üniversite Öğrencilerine Yönelik Girişimcilik Ölçeği-ÜÖYGÖ"nden Aldıkları Ortalama Puanlar

\begin{tabular}{lrrrrr}
\hline ÖLÇEKLER & N & Min. & Max. & Ort. & SS \\
\hline Sosyo-bilimsel Konulara Yönelik Tutum Ölçeği (SKYTÖ) & 88 & 2.90 & 4.73 & 3.90 & .457 \\
\hline Sosyo-bilimsel konuların yarar ve önemi (SKYÖ) & 88 & 2.82 & 5.00 & 4.07 & .490 \\
\hline Sosyo-bilimsel konulardan hoşlanma (SKH) & 88 & 2.29 & 5.00 & 3.73 & .586 \\
\hline Sosyo-bilimsel konulara yönelik kaygı (SKYK) & 88 & 1.67 & 4.83 & 3.64 & .679 \\
\hline Üniversite Öğrencilerine Yönelik Girişimcilik Ölçeği (ÜÖYGÖ) & 88 & 2.36 & 5.00 & 3.91 & .499 \\
\hline
\end{tabular}

Tablo 1 incelendiğinde, sınıf öğretmen adaylarının “Sosyo-bilimsel Konulara Yönelik Tutum Ölçeği” nden aldıkları ortalama puanların 5 üzerinden 3.90 puan, bu puanın karşılığının "sık sık” kategorisinde olduğu;"Sosyo-bilimsel konuların yarar ve önemi" alt boyutundan 5 üzerinden 4.07 puan, bu puanın karşılığının "sık sık" kategorisinde olduğu; "Sosyo-bilimsel konulardan hoşlanma" alt boyutundan 5 üzerinden 3.73 puan, bu puanın karşılığının "sık sık" kategorisinde olduğu ve "Sosyo-bilimsel konulara yönelik kayg1" alt boyutundan 5 üzerinden 3.64 puan olduğu, bu puanın karşılığının "sık sık" kategorisinde olduğu görülmüştür. Benzer şekilde, “Üniversite Öğrencilerine Yönelik Girişimcilik Ölçeği (ÜÖYGÖ)” den 5 üzerinden 3.91 puan aldıkları, bu puanın karşılığının ise "katılıyorum" kategorisinde 
olduğu görülmüştür. Bu durum sınıf öğretmeni adaylarının yüksek girişimcilik düzeyine sahip olduğunu göstermektedir.

Tablo 2'de sınıf öğretmeni adaylarının “Üniversite Öğrencilerine Yönelik Girişimcilik Ölçeği (ÜÖYGÖ)" ile "Sosyo-bilimsel Konulara Yönelik Tutum Ölçeği (SKYTÖ)" ve alt boyutlarından (Sosyo-bilimsel konuların yarar ve önemi-SKYÖ, Sosyo-bilimsel konulardan hoşlanma-SKH ve Sosyo-bilimsel konulara yönelik kayg1SKYK) aldıkları puanlar arasındaki ilişki verilmiştir.

Tablo 2.

Sinıf Öğretmeni Adaylarmın "Üniversite Öğrencilerine Yönelik Girişimcilik Ölçeği (ÜÖYGÖ)" ile "Sosyo-bilimsel Konulara Yönelik Tutum Ölçeği (SKYTÖ)" ve Alt Boyutlarndan (Sosyo-bilimsel konularn yarar ve önemi-SKYÖ, Sosyo-bilimsel konulardan hoşlanma-SKH ve Sosyo-bilimsel konulara yönelik kaygı-SKYK) Aldıkları Puanlar Arasındaki İlişki

\begin{tabular}{llllll}
\hline \multicolumn{5}{c}{ Korelasyonlar } \\
\hline \multirow{2}{*}{ ÜÖYGÖ } & SKYÖ & SKH & SKYK & SKYTÖ \\
\cline { 2 - 6 } & Pearson Correlation & $.550^{* *}$ & $.559^{* *}$ & .179 & $.554^{* *}$ \\
\cline { 2 - 6 } & Sig. (2-tailed) & .000 & .000 & .095 & .000 \\
\cline { 2 - 6 } & $\mathrm{N}$ & 88 & 88 & 88 & 88 \\
\hline
\end{tabular}

**Korelasyon $p=0.01$ düzeyinde anlamlıdır.

Tablo 2 incelendiğinde, sınıf öğretmeni adaylarının “Üniversite Öğrencilerine Yönelik Girişimcilik Ölçeği (ÜÖYGÖ)" ve "Sosyo-bilimsel Konulara Yönelik Tutum Ölçeği (SKYTÖ)" nden aldıkları puanlar arasında orta düzeyde pozitif bir ilişkinin ( $r=0.554)$ olduğu görülmüştür. Ayrıca Üniversite Öğrencilerine Yönelik Girişimcilik Ölçeği (ÜÖYGÖ) ile SKYTÖ’nün “Sosyo-bilimsel konuların yarar ve önemi (SKYÖ)" adlı alt boyutu arasında orta düzeyde pozitif bir ilişkinin ( $\mathrm{r}=0.550)$ olduğu benzer şekilde "Üniversite Öğrencilerine Yönelik Girişimcilik Ölçeği (ÜÖYGÖ)" ile SKYTÖ'nün "Sosyo-bilimsel konulardan hoşlanma (SKH)" alt boyutu arasında orta düzeyde pozitif bir ilişkinin $(r=0.559)$ olduğu görüşmüştür.

\section{Öğretmen Adayları Tarafından Tasarlanan Ders Planlarından Elde Edilen Nitel Bulgular}

Sosyo-bilimsel konulara ilişkin yapılan alan yazın taraması sonucunda sosyo-bilimsel konulara ait temalar şu şekilde ortaya çıkmıştır: Sosyo- bilimsel konulara ilişkin temalar; ozon tabakası, atıkları depolama, organ bağışı, canlı çeşitliliğini koruma, çevresel eylemler, doğal kaynakları koruma, beslenme önerileri (obezite), yoksulluk, kirlilik, genetik ve üreme teknolojileri, embriyo seçimi, enerjinin korunumu, GDO, klonlama, nükleer enerji, salgın hastalıklar, biyoteknoloji, uzay araştırmaları, küresel ısınma, alternatif enerji kaynaklarıdır. Yukarıda sayılan temalar yapılan doküman incelemesinde ölçütler olarak kullanılmış, ancak yapılan doküman analizinin sonucunda öğretmen adayları tarafından tasarlanan ders plânlarında karşılık bulan temalar ise: Atıkları depolama, organ bağışı, çevresel eylemler, doğal kaynakları 
koruma, beslenme önerileri (obezite), yoksulluk, kirlilik, GDO ve küresel ısınma şeklindedir.

Tablo 3.

Sınıf Öğretmeni Adaylarının Ders Plânlarında "Sosyo-Bilimsel" Boyutuna İlişkin Ortaya Çıkan Temalar

\begin{tabular}{|c|c|c|}
\hline $\begin{array}{l}\text { Sosyo-Bilimsel } \\
\text { Boyutlar }\end{array}$ & $\begin{array}{l}\text { Sosyal Bilgiler Öğretim Programına } \\
\text { Ait Kazanımlar }\end{array}$ & $\begin{array}{l}\text { Fen Bilimleri Öğretim Programına } \\
\text { Ait Kazanımlar }\end{array}$ \\
\hline Atıkları Depolama & $\begin{array}{l}\text { SB.4.5.5. Çevresindeki kaynakları } \\
\text { israf etmeden kullanır. }\end{array}$ & \\
\hline Organ Bağışı & $\begin{array}{l}\text { SB.4.1.4. Kendisini farklı özelliklere } \\
\text { sahip diğer bireylerin yerine koyar. }\end{array}$ & \\
\hline Çevresel Eylemler & $\begin{array}{l}\text { SB.4.6.3. Okul yaşamında gerekli } \\
\text { gördüğ̈ü eğitsel sosyal etkinlikleri } \\
\text { önerir. }\end{array}$ & \\
\hline \multirow[t]{3}{*}{$\begin{array}{l}\text { Doğal kaynakları } \\
\text { koruma }\end{array}$} & $\begin{array}{l}\text { SB.4.5.5. Çevresindeki kaynakları } \\
\text { israf etmeden kullanır. }\end{array}$ & $\begin{array}{l}\text { F.4.2.1.1. Canlı yaşamı ve besin } \\
\text { içerikleri arasındaki ilişkiyi açılar. }\end{array}$ \\
\hline & $\begin{array}{l}\text { SB.4.4.5. Teknolojik ürünleri } \\
\text { kendisine, başkalarına ve doğaya } \\
\text { zarar vermeden kullanır. }\end{array}$ & $\begin{array}{l}\text { F.4.6.1.1. Kaynakların kullanımında } \\
\text { tasarruflu davranmaya özen gösterir. }\end{array}$ \\
\hline & $\begin{array}{l}\text { SB.4.4.2. Teknolojik ürünlerin } \\
\text { geçmişteki ve bugünkü } \\
\text { kullanımlarını karşılaştırır. }\end{array}$ & $\begin{array}{l}\text { F.4.4.5.3. Karışımların ayrılmasını, } \\
\text { ülke ekonomisine katkısı ve } \\
\text { kaynakların etkili kullanımı } \\
\text { bakımından tartışır. }\end{array}$ \\
\hline \multirow[t]{2}{*}{$\begin{array}{l}\text { Beslenme önerileri } \\
\text { ve obezite }\end{array}$} & $\begin{array}{l}\text { SB.4.4.2. Teknolojik ürünlerin } \\
\text { geçmişteki ve bugünkü } \\
\text { kullanımlarını karşılaştırır. }\end{array}$ & $\begin{array}{l}\text { F.4.2.1.4. İnsan sağllğı ile dengeli } \\
\text { beslenmeyi ilişkilendirir. }\end{array}$ \\
\hline & $\begin{array}{l}\text { SB.4.2.3. Geleneksel çocuk oyunlarını } \\
\text { değişim ve süreklilik açısından } \\
\text { günümüzdeki oyunlarla karşılaştırır. }\end{array}$ & $\begin{array}{l}\text { F.4.2.1.3. Sağlıklı bir yaşam için } \\
\text { besinlerin tazeliğinin ve doğallığının } \\
\text { önemini, araştırma verilerine dayalı } \\
\text { olarak } \\
\text { tartıșır. }\end{array}$ \\
\hline
\end{tabular}

Yoksulluk

SB.4.5.5. Çevresindeki kaynakları

israf etmeden kullanir.

SB.4.6.1. Çocuk olarak sahip olduğu

haklara örnekler verir.

SB.4.5.2. Ailesi ve yakın çevresindeki

başlıca ekonomik faaliyetleri tanır.

Kirlilik

SB.4.4.2. Teknolojik ürünlerin

F.3.5.4.3. Şiddetli seslerin işitme geçmişteki ve bugünkü kaybına sebep olabileceğini ifade kullanımlarını karşılaştırır. eder. 


\begin{tabular}{|c|c|c|}
\hline & $\begin{array}{l}\text { SB.4.4.5. Teknolojik ürünleri } \\
\text { kendisine, başkalarına ve doğaya } \\
\text { zarar vermeden kullanır. }\end{array}$ & $\begin{array}{l}\text { F.4.5.3.1. Işık kirliliğinin nedenlerini } \\
\text { sorgular. }\end{array}$ \\
\hline & $\begin{array}{l}\text { SB.4.5.5. Çevresindeki kaynakları } \\
\text { israf etmeden kullanır. }\end{array}$ & $\begin{array}{l}\text { F.4.5.5.1. Ses kirliliğinin nedenlerini } \\
\text { sorgular. }\end{array}$ \\
\hline & & $\begin{array}{l}\text { F.4.5.5.3. Ses kirliliğini azaltmaya } \\
\text { yönelik çözümler üretir. }\end{array}$ \\
\hline & & $\begin{array}{l}\text { F.4.4.5.3. Karışımların ayrılmasını, } \\
\text { ülke ekonomisine katkısı ve } \\
\text { kaynakların etkili kullanımı } \\
\text { bakımından tartışır. }\end{array}$ \\
\hline \multirow[t]{4}{*}{ GDO } & & $\begin{array}{l}\text { F.4.2.1.3. Sağlıklı bir yaşam için } \\
\text { besinlerin tazeliğinin ve doğallığının } \\
\text { önemini, araştırma verilerine dayalı } \\
\text { olarak } \\
\text { tartışır. }\end{array}$ \\
\hline & & $\begin{array}{l}\text { F.4.2.1.4. İnsan sağlı̆̆ ile dengeli } \\
\text { beslenmeyi ilişkilendirir. }\end{array}$ \\
\hline & & $\begin{array}{l}\text { F.4.2.1.5. Alkol ve sigara } \\
\text { kullanımının insan sağlığına olan } \\
\text { olumsuz etkilerinin farkına varır. }\end{array}$ \\
\hline & & $\begin{array}{l}\text { F.4.2.1.6. Yakın çevresinde sigara } \\
\text { kullanımını azaltmaya yönelik } \\
\text { sorumluluk üstlenir. }\end{array}$ \\
\hline \multirow[t]{4}{*}{ Küresel 1sınma } & $\begin{array}{l}\text { SB.4.5.5. Çevresindeki kaynakları } \\
\text { israf etmeden kullanır. }\end{array}$ & \\
\hline & $\begin{array}{l}\text { SB.4.4.5. Teknolojik ürünleri } \\
\text { kendisine, başkalarına ve doğaya } \\
\text { zarar vermeden kullanır. }\end{array}$ & \\
\hline & $\begin{array}{l}\text { SB.4.3.4. Çevresinde meydana gelen } \\
\text { hava olaylarını gözlemleyerek } \\
\text { bulgularını resimli grafiklere aktarır. }\end{array}$ & \\
\hline & $\begin{array}{l}\text { SB.4.4.2. Teknolojik ürünlerin } \\
\text { geçmişteki ve bugünkü } \\
\text { kullanımlarını karşılaştırır. }\end{array}$ & \\
\hline
\end{tabular}

Öğretmen adaylarının hazırladıkları ders planları incelendiğinde sosyobilimsel konuların bir kısmına sosyal bilgiler dersine ait kazanımlar aracılığıyla bazılarına ise fen bilimleri dersine ait kazanımlar aracılı̆̆ıyla değindikleri, bir kısmına ise hiç değinilmediği ortaya çıkmıştır. Bu durumun, hazırlanan ders planlarının ilkokul düzeyinde olmasından kaynaklandığı düşünülebilir. Çünkü ilkokul fen bilimleri ve sosyal bilgiler dersi öğretim programında yer alan kazanımlar incelendiğinde birçok konuda temel düzeyde bilgi ve farkındalık 
oluşturmanın hedeflediği görülmektedir. Ancak öğretim programlarındaki kazanımlarla ilişkilendirme şansı olmasına karşın canlı çeşitliliği, salgın hastalıklar, uzay araştırmaları gibi sosyo-bilimsel konulara hiç değinilmemiş olması da öğretmen adaylarının tekdüze bakış açısına sahip olduklarını düşündürmektedir. Ders planlarında yer verilen sosyo-bilimsel konulara ait temalardan küresel 1sınma, yoksulluk, atıkları depolama, organ bağışı ve çevresel eylemler temaları fen bilimleri dersi ile ilgili olarak öğretmen adaylarının tasarladığı ders planlarında yer almazken; GDO temasına ise sosyal bilgiler dersi bağlamında öğretmen adayları tarafından tasarlanan planlarda yer verilmemiştir.

Hem fen bilimleri hem de sosyal bilgiler dersi öğretim programlarına göre hazırlanan ders planlarında ortak olarak yer verilen sosyo-bilimsel konular, kirlilik, beslenme ve obezite ile doğal kaynakları korumadır. Örneğin sosyal bilgiler dersi bağlamında "geleneksel çocuk oyunlarını değişim ve süreklilik açısından günümüzdeki oyunlarla karşılaştırır" kazanımında geleneksel oyunların ağırlıklı olarak açık hava da ve fiziksel aktiviteyi gerektiren oyunlar olduğu ancak günümüz dünyasında bilgisayar başında sanal oyunların oynaması ile obezitenin tetiklendiği ifade edilmiştir. Bu bağlamda, üç sosyo-bilimsel konuya ilişkin hem fen bilimleri hem sosyal bilgiler dersi öğretim programlarında doğrudan kazanımların yer alması etkili olabilir.

Öğretmen adaylarının Sosyal Bilgiler Dersi Öğretim Programı'nda yer alan kazanımları temel alarak hazırladıkları ders planlarında yer alan sosyo-bilimsel konular; atıkları depolama, organ bağışı, çevresel eylemler, doğal kaynakları koruma, beslenme önerileri (obezite), yoksulluk, kirlilik, küresel 1sınmadır. Bu konuların, "Bilim, teknoloji ve toplum", "Insanlar, yerler ve çevreler", "Birey ve Toplum", "Etkin Vatandaşlık" öğrenme alanlarında yer alan kazanımlarla örtüşmesi etkili olabilir.

Sosyo-bilimsel konulara "Atıkları Depolama" boyutu ile tasarladığı Sosyal Bilgiler dersi planında yer veren bir öğretmen adayı atıkları depolamayı geri dönüşüm ile ilişkilendirerek şu şekilde yer vermiştir:

"Kaynakların israf edilmesinin ve çöplerin küresel ısınma ile ilişkisi üzerinde durularak ögrrenciler bir geri dönüşüm tesisine alan gezisine götürülür (P.40)"

Bir öğretmen adayı sosyo-bilimsel konulara yönelik tasarladığı Sosyal Bilgiler dersi planında "Organ bağışı" boyutu ile şu şekilde yer vermiştir:

"Kendini farklı özelliklere sahip (engelli, sağlık sorunları yaşayan) bireylerin yerine koymaların sağlayacak empati etkinlikleri örnek olaylar üzerinden gerçekleştirilerek organ bağışının önemine vurgu yapılır. öğrencilerin organ bağışı konulu afişler tasarlayıp okulun yakın çeoresindeki çeşitli yerlere izin alarak afişleri asmalar sağlanır (P.77)

Bir öğretmen adayı sosyo-bilimsel konulara yönelik tasarladığı Sosyal Bilgiler dersi planında "Çevresel eylemler" boyutu ile şu şekilde yer vermiştir:

"Öğrencilerden yakın çevrelerinde belirledikleri çevresel sorunlarn gözlemleyerek not almalar istenir. (ă̆açlandırma, çevre kirliliği, atıklarn sinıflandırma ve dönüştürme, sokak hayvanlarının bakımı...vb) Belirlenen sorunlar tahtaya yazılıp öğrenciler gruplara ayrlarak farkl tür etkinliklerden (sokak hayvanlarına yiyecek ve su temin 
etme, ă̆aç dikme, pankart hazırlama) istediklerini seçip grup arkadaşları ile çevresel eylemler gerçekleştirmeleri istenir (P41)"

Bir öğretmen adayı sosyo-bilimsel konulara yönelik tasarladığı Sosyal Bilgiler dersi planında "Doğal kaynakları koruma" boyutuna kaynakları israf etmeden kullanma biçiminde şu şekilde yer vermiştir:

"Ailelerinin farklı türdeki (elektrik, su, kağıt...vb) tüketimlerini gözlemleri istenen ögrencilerin bu tüketimlerde israfi önlemeye yönelik fikirler geliştirmeleri ve proje üretmeleri istenir (P. 59)"

Bir öğretmen adayı sosyo-bilimsel konulara tasarladığı Sosyal Bilgiler dersi planında "Obezite" boyutuna çocuk oyunları ile ilişkilendirerek şu şekilde yer vermiştir:

"Öğrencilere geçmişte oynanan çocuk oyunları ile ilgili sokak röportajı yapma görevi verilir. Sonra da okuldaki öğrencilerle günümüz çocuk oyunlarn ile ilgili görüşmeler yaparlar. Geçmişteki ve günümüzdeki çocuk oyunları karşılaştırılarak dijitalleşme ve sürekli teknolojik araçlar ile oynamanın să̆lık üzerindeki olumsuz etkileri (obezite, asosyallik, görme bozuklukları...vb) üzerinde durulur. Geçmişte oynanan oyunlardan bazıları sinıfta oynanır (P55)"

Bir öğretmen adayı sosyo-bilimsel konulara yönelik tasarladığı Sosyal Bilgiler dersi planında "Yoksulluk" boyutuna çocuk hakları ile ilişkilendirerek şu şekilde yer vermiştir:

"Medyada çıkan yoksulluk, savaş, çocuk işçiler gibi haberler gruplar halinde tartışılarak öğrencilerin bir çocuk hakları sözleşmesi yazması istenir. sonra gerçek çocuk hakları sözleşmesi yansıtılarak kendi yazdıkları çocuk hakları sözleşmesi ile maddeleri karşılaştırmaları istenir (P.54)"

Bir öğretmen adayı sosyo-bilimsel konulara yönelik tasarladığı Sosyal Bilgiler dersi planında "Kirlilik" boyutuna teknolojik ürünleri doğaya, kendine ve başkasına zarar vermeden kullanma ile ilişkilendirerek şu şekilde yer vermiştir:

"Teknoloji yararlıdır/zararlıdır biçiminde münazara yapılır. Çevre kirliliğine sebep olmadan nasıl teknolojik aletlerin kullanılabileceğine ilişkin kullanma kılavuzları hazırlanır (P.53)"

Bir öğretmen adayı sosyo-bilimsel konulara yönelik tasarladığı Sosyal Bilgiler dersi planında "Küresel Isınma" boyutuna şu şekilde yer vermiştir:

"Hava olayların gözlemleme ve geçmişten günümüze iklim değişiklikleri konusunda medya araştırmaları yapılır. Öğrencilerin küresel ısınma konulu öykü ve slogan yazmalarn istenir (P.58)"

Öğretmen adaylarının Fen Bilimleri Dersi Öğretim Programı'nda yer alan kazanımları temel alarak hazırladikları ders planlarında yer alan sosyo-bilimsel konular, doğal kaynakları koruma, beslenme ve obezite, kirlilik ve GDO'dur. Bu sosyo-bilimsel konuların seçiminde öğretim programında yer alan "Canlılar ve yaşam" ile "Fiziksel Olaylar" öğrenme alanlarında yer alan kazanımlarla bu konuların birebir örtüşüyor olmasının etkili olduğu düşünülebilir. 
Bir öğretmen adayı sosyo-bilimsel konulara yönelik tasarladı̆̆ 1 Fen Bilimleri dersi planında "Doğal kaynakları koruma" boyutu ile şu şekilde yer vermiştir:

"Öğrenciler besinler hakkında edindikleri bilgileri günlük yaşamlarında kullanarak ve israf konusunda duyarl birer birey olarak insanlara örnek olurlar. Ayrica öğrencilerden evlerde çöplerin nasıl düzenli ayrılması gerektiğine ve ülke ekonomisine nasıl katkı sunulacağına yönelik proje tasarlamaları beklenir (P83)"

"Öğrencilerden toplumun teknolojik aletlerin kullanım kılavuzunu dikkat ederek kullanıp kullanmadıkların, kullanmadıklarında ne gibi sorunlarla karşılaştıklarını, kendilerine, başkalarına ve doğaya zarar vermemeleri için kullanım kılavuzundaki uyarıları dikkate almalarnın önemi üzerinde durmaları beklenir P7)"

Bir öğretmen adayı sosyo-bilimsel konulara yönelik tasarladığı Fen Bilimleri dersi planında "Beslenme önerileri (obezite)" boyutu ile şu şekilde yer vermiştir:

"Öğrencilere yapılacak etkinlikler yoluyla sağhlksız beslendiklerinde vücudun yă̆ oluşumunda olumsuz yönde ve kalıcı şekilde etkisi olduğu ayrica paketlenmiş gıdaların içindeki yağların zararlı olduğu kazandırılır (P91)"

Bir öğretmen adayı sosyo-bilimsel konulara yönelik tasarladığı Fen Bilimleri dersi planında "Yoksulluk" boyutu ile şu şekilde yer vermiştir:

"Öğrencilerden ekonomik faaliyetlerin nasıl gittiğini, düzenin nasıl oluştuğunu görebilmek için yakın çevresindeki gözlemlerinden yola çıkmaları istenir. Ayrıca ögrencilerin ekonomik faaliyetler konusunda bir etkinlik tasarlamarn istenir. Etkinlik kapsamında ekonomik faaliyetlerin günlük yaşamda kullanım alanların geniş bir kitleyle araştırmaları istenerek bu araştırma sonuçlarında yaratıcılıklarını kullanarak gelir, gider, bütçe gibi durumlar hakkında yeni fikirler oluşturmaları istenir. (P6)"

Bir öğretmen adayı sosyo-bilimsel konulara yönelik tasarladığı Fen Bilimleri dersi planında "Kirlilik" boyutu ile şu şekilde yer vermiştir:

"Öğrencilerden çevre kirliliği ile ilgili çevre ve ülke ekonomisine katkı sağlayacak projeler tasarlamalan istenir (P93)"

Bir öğretmen adayı sosyo-bilimsel konulara yönelik tasarladığ1 Fen Bilimleri dersi planında "GDO" boyutu ile şu şekilde yer vermiştir:

"Öğrenciler kendi aralarında dondurulmuş besinler hakkında tartışırlar. Tartışma sonucunda taze besinlerin vitamin ve minarek yönden dondurulmuş besinlere göre daha zengin olduğu, taze olmayan besinlerin vitamin değerlerini yitirdiği, besinlerin tazeliğinin ve doğallı̆̆ının sağh̆̆̆ımız için önemli olduğunu öğrenciler tarafindan açıklanır. Ayrıca öğrencilerin GDO'lu besinler hakkında detaylı bir araştırma yapmalarına olanak sağlanır (P95)"

Öğretmen adaylarının tasarladıkları ders planlarında girişimciliğe ait temalar: proaktiflik (öncü olma), fırsatları fark etme, yenilikçilik ve yaratıcılık (iş fikri belirleme), kaynakları etkili kullanma, maliyet analizi, risk alma, sorumluluk alma, yönetsel yetkinlik, planlama, ikna ve iletişim, pazarlama stratejileri, rekabetçi düşünme, farklı alanlara uyarlama ve değerlendirme şeklindedir. 
Tablo 4.

Sınıf Öğretmeni Adaylarının Ders Plânlarında "Girişimcilik" Boyutuna İlişkin Ortaya Çıkan Temalar

\begin{tabular}{|c|c|c|}
\hline $\begin{array}{l}\text { Girişimcilik } \\
\text { boyutuna ait temalar }\end{array}$ & $\begin{array}{l}\text { Sosyal Bilgiler Öğretim Programına } \\
\text { Ait Kazanımlar }\end{array}$ & $\begin{array}{l}\text { Fen Bilimleri Öğretim Programına } \\
\text { Ait Kazanımlar }\end{array}$ \\
\hline $\begin{array}{l}\text { Proaktiflik (Öncü } \\
\text { Olma) }\end{array}$ & $\begin{array}{l}\text { SB.4.6.1. Çocuk olarak sahip olduğu } \\
\text { haklara örnekler verir. }\end{array}$ & \\
\hline Firsatları fark etme & $\begin{array}{l}\text { SB.4.5.5. Çevresindeki kaynakları } \\
\text { israf etmeden kullanır. }\end{array}$ & \\
\hline \multirow[t]{4}{*}{$\begin{array}{l}\text { Yenilikçilik ve } \\
\text { yaratıcılık }\end{array}$} & $\begin{array}{l}\text { SB.4.5.5. Çevresindeki kaynakları } \\
\text { israf etmeden kullanır. }\end{array}$ & $\begin{array}{l}\text { F.4.5.1.2. Gelecekte kullanılabilecek } \\
\text { aydınlatma araçlarına yönelik } \\
\text { tasarım yapar. }\end{array}$ \\
\hline & $\begin{array}{l}\text { SB.4.4.4. Çevresindeki ihtiyaçlardan } \\
\text { yola çıkarak kendine özgü ürünler } \\
\text { tasarlamaya yönelik fikirler geliştirir. }\end{array}$ & $\begin{array}{l}\text { F.4.5.1.1. Geçmişte ve günümüzde } \\
\text { kullanılan aydınlatma araçlarını } \\
\text { karşılaştırır. }\end{array}$ \\
\hline & $\begin{array}{l}\text { SB.4.4.3. Kullandiğı teknolojik } \\
\text { ürünlerin mucitlerini ve bu ürünlerin } \\
\text { zaman içerisindeki gelişimini } \\
\text { araştırır. }\end{array}$ & $\begin{array}{l}\text { F.4.5.1.2. Gelecekte kullanılabilecek } \\
\text { aydınlatma araçlarına yönelik } \\
\text { tasarım yapar. }\end{array}$ \\
\hline & $\begin{array}{l}\text { SB.4.4.2. Teknolojik ürünlerin } \\
\text { geçmişteki ve bugünkü } \\
\text { kullanımlarını karşılaştırır. }\end{array}$ & \\
\hline \multirow[t]{4}{*}{$\begin{array}{l}\text { Kaynakları etkili } \\
\text { kullanma }\end{array}$} & $\begin{array}{l}\text { SB.4.5.5. Çevresindeki kaynakları } \\
\text { israf etmeden kullanır. }\end{array}$ & \\
\hline & $\begin{array}{l}\text { SB.4.4.2. Teknolojik ürünlerin } \\
\text { geçmişteki ve bugünkü } \\
\text { kullanımlarını karşılaştırır. }\end{array}$ & \\
\hline & $\begin{array}{l}\text { SB.4.4.4. Çevresindeki ihtiyaçlardan } \\
\text { yola çıkarak kendine özgü ürünler } \\
\text { tasarlamaya yönelik fikirler geliştirir. }\end{array}$ & \\
\hline & $\begin{array}{l}\text { SB.4.4.5. Teknolojik ürünleri } \\
\text { kendisine, başkalarına ve doğaya } \\
\text { zarar vermeden kullanır. }\end{array}$ & \\
\hline Maliyet analizi & $\begin{array}{l}\text { SB.4.5.1. İstek ve ihtiyaçlarını ayırt } \\
\text { ederek ikisi arasında bilinçli seçimler } \\
\text { yapar. }\end{array}$ & \\
\hline \multirow[t]{2}{*}{ Sorumluluk alma } & $\begin{array}{l}\text { SB.4.3.3. Yaşadığı çevredeki doğal ve } \\
\text { beşerî unsurları ayırt eder. }\end{array}$ & $\begin{array}{l}\text { F.4.5.3.1. Işık kirliliăginin } \\
\text { nedenlerini sorgular. }\end{array}$ \\
\hline & $\begin{array}{l}\text { SB.4.4.2. Teknolojik ürünlerin } \\
\text { geçmişteki ve bugünkü } \\
\text { kullanımlarını karşılaştıırı. }\end{array}$ & $\begin{array}{l}\text { F.4.2.1.1. Canlı yaşamı ve besin } \\
\text { içerikleri arasındaki ilişkiyi açıklar. }\end{array}$ \\
\hline
\end{tabular}




\begin{tabular}{|c|c|c|}
\hline & $\begin{array}{l}\text { SB.4.4.5. Teknolojik ürünleri } \\
\text { kendisine, başkalarına ve doğaya } \\
\text { zarar vermeden kullanır. }\end{array}$ & $\begin{array}{l}\text { F.4.6.1.1. Kaynakların kullanımında } \\
\text { tasarrufu davranmaya özen } \\
\text { gösterir. }\end{array}$ \\
\hline & $\begin{array}{l}\text { SB.4.1.4. Kendisini farklı özelliklere } \\
\text { sahip diğer bireylerin yerine koyar. }\end{array}$ & $\begin{array}{l}\text { F.4.6.1.2. Yaşam için gerekli olan } \\
\text { kaynakların ve geri dönüşümün } \\
\text { önemini fark eder. }\end{array}$ \\
\hline & $\begin{array}{l}\text { SB.4.5.5. Çevresindeki kaynakları } \\
\text { israf etmeden kullanır. }\end{array}$ & \\
\hline \multirow[t]{2}{*}{ Yönetsel yetkinlik } & $\begin{array}{l}\text { SB.4.3.6. Doğal afetlere yönelik } \\
\text { gerekli hazırlıkları yapar. }\end{array}$ & \\
\hline & $\begin{array}{l}\text { SB.4.4.5. Teknolojik ürünleri } \\
\text { kendisine, başkalarına ve doğaya } \\
\text { zarar vermeden kullanır. }\end{array}$ & \\
\hline \multirow[t]{3}{*}{ Planlama } & $\begin{array}{l}\text { SB.4.3.6. Doğal afetlere yönelik } \\
\text { gerekli hazırlıkları yapar. }\end{array}$ & \\
\hline & $\begin{array}{l}\text { SB.4.4.5. Teknolojik ürünleri } \\
\text { kendisine, başkalarına ve doğaya } \\
\text { zarar vermeden kullanır. }\end{array}$ & \\
\hline & $\begin{array}{l}\text { SB.4.3.4. Çevresinde meydana gelen } \\
\text { hava olaylarını gözlemleyerek } \\
\text { bulgularını resimli grafiklere aktarır. }\end{array}$ & \\
\hline \multirow[t]{7}{*}{ İkna ve iletişim } & $\begin{array}{l}\text { SB.4.1.4. Kendisini farklı özelliklere } \\
\text { sahip diğer bireylerin yerine koyar. }\end{array}$ & $\begin{array}{l}\text { F.4.5.3.1. Işık kirliliğinin } \\
\text { nedenlerini sorgular. }\end{array}$ \\
\hline & $\begin{array}{l}\text { SB.4.2.3. Geleneksel çocuk oyunlarını } \\
\text { değişim ve süreklilik açısından } \\
\text { günümüzdeki oyunlarla karşılaştırır. }\end{array}$ & $\begin{array}{l}\text { F.4.2.1.3. Sağlıklı bir yaşam için } \\
\text { besinlerin tazeliğinin ve } \\
\text { doğallığının önemini, araştırma } \\
\text { verilerine dayalı olarak } \\
\text { tartışır. }\end{array}$ \\
\hline & $\begin{array}{l}\text { SB.4.5.5. Çevresindeki kaynakları } \\
\text { israf etmeden kullanır. }\end{array}$ & $\begin{array}{l}\text { F.4.5.5.1. Ses kirliliğinin nedenlerini } \\
\text { sorgular. }\end{array}$ \\
\hline & $\begin{array}{l}\text { SB.4.7.4. Farklı kültürlere sayg1 } \\
\text { gösterir. }\end{array}$ & $\begin{array}{l}\text { F.4.2.1.3. Sağlıklı bir yaşam için } \\
\text { besinlerin tazeliğinin ve } \\
\text { doğallığının önemini, araştırma } \\
\text { verilerine dayalı olarak tartışır. }\end{array}$ \\
\hline & $\begin{array}{l}\text { SB.4.2.3. Geleneksel çocuk oyunlarını } \\
\text { değişim ve süreklilik açısından } \\
\text { günümüzdeki oyunlarla karşılaştırır. }\end{array}$ & \\
\hline & $\begin{array}{l}\text { SB.4.4.2. Teknolojik ürünlerin } \\
\text { geçmişteki ve bugünkü } \\
\text { kullanımlarını karşılaştırır. }\end{array}$ & \\
\hline & $\begin{array}{l}\text { SB.4.4.5. Teknolojik ürünleri } \\
\text { kendisine, başkalarına ve doğaya }\end{array}$ & \\
\hline
\end{tabular}




\begin{tabular}{|c|c|c|}
\hline & zarar vermeden kullanır. & \\
\hline & $\begin{array}{l}\text { SB.4.6.1. Çocuk olarak sahip olduğu } \\
\text { haklara örnekler verir. }\end{array}$ & \\
\hline \multirow[t]{2}{*}{ Pazarlama stratejileri } & $\begin{array}{l}\text { SB.4.4.2. Teknolojik ürünlerin } \\
\text { geçmişteki ve bugünkü } \\
\text { kullanımlarını karşılaştırır. }\end{array}$ & $\begin{array}{l}\text { F.4.5.3.1. Işık kirliliğinin } \\
\text { nedenlerini sorgular. }\end{array}$ \\
\hline & $\begin{array}{l}\text { SB.4.4.4. Çevresindeki ihtiyaçlardan } \\
\text { yola çıkarak kendine özgü ürünler } \\
\text { tasarlamaya yönelik fikirler geliştirir }\end{array}$ & $\begin{array}{l}\text { F.4.5.1.1. Geçmişte ve günümüzde } \\
\text { kullanılan aydınlatma araçlarını } \\
\text { karşılaştırır. }\end{array}$ \\
\hline Rekabetçi düşünme & $\begin{array}{l}\text { SB.4.4.2. Teknolojik ürünlerin } \\
\text { geçmişteki ve bugünkü } \\
\text { kullanımlarını karşılaştırır. }\end{array}$ & \\
\hline \multirow[t]{2}{*}{$\begin{array}{l}\text { Farkli alanlara } \\
\text { uyarlama }\end{array}$} & & $\begin{array}{l}\text { F.4.3.2.4. Miknatısların yeni } \\
\text { kullanım alanları konusunda } \\
\text { fikirlerini açıklar. }\end{array}$ \\
\hline & & $\begin{array}{l}\text { F.4.5.5.1. Ses kirliliğinin nedenlerini } \\
\text { sorgular. }\end{array}$ \\
\hline
\end{tabular}

Öğretmen adaylarının sosyal bilgiler ve fen bilimleri dersi bağlamında tasarladıkları ders planlarında çeşitli kazanımlarla ilişkilendirerek yer verdikleri girişimcilik boyutuna ilişkin temalar: Proaktiflik (Öncü Olma),firsatları fark etme, yenilikçilik ve yaratıcılık, kaynakları etkili kullanma, maliyet analizi, sorumluluk alma, yönetsel yetkinlik, planlama, ikna ve iletişim, pazarlama stratejileri, rekabetçi düşünme, farklı alanlara uyarlama biçimindedir. Öğretmen adaylarının sosyal bilgiler dersinde girişimciliği ilişkilendirdikleri kazanımlara ait temalar göz önünde bulundurulduğunda programda yer alan sekiz öğrenme alanından yedisi ile girişimciliği ilişkilendirdikleri ortaya çıkmıştır. Öğretmen adaylarının fen bilimleri dersinde girişimciliği ilişkilendirdikleri kazanımlara ait temalar incelendiğinde ise öğretmen adaylarının girişimciliğ̈i programda yer alan iki öğrenme alanını kullanarak (Canlılar ve Yaşam ile Fiziksel Olaylar) ele aldıkları görülmüştür.

Bir öğretmen adayı tasarladı̆̆ı ders planında girişimciliğe "Proaktiflik" teması altında şu şekilde yer vermiştir:

“Öğrencilerin çocuk haklarn sözleşmesinde yer almayan ancak günümüz koşullarında sözleşmede yer alması gerektiğini düşündükleri maddeleri tartışmaları istenir. kendi çocuk hakları sözleşmelerini yazmaları istenir (P.54)"

Bir öğretmen adayı tasarladığı ders planında girişimciliğe "Fırsatları fark etme" teması altında şu şekilde yer vermiştir:

"Yağmur sularm biriktirme ile ilgili bir düzenek tasarlamaları ve bu durumu firsata dönüştürerek sosyal yarar sağlayacak biçimde projelendirmeleri istenir (P.32)" 
Bir öğretmen adayı tasarladığı ders planında girişimciliğe "Yenilikçilik ve yaratıcılık" teması altında şu şekilde yer vermiştir:

"Ekmek israfi, su israfi, elektrik israfi gibi konularda yaratıcı çözümler içeren broşür hazırlamaları ve farkl bilgisayar programları kullanarak görsel açıdan zenginleştirmeleri istenir (P. 34)"

Bir öğretmen adayı tasarladığı ders planında girişimciliğe "Kaynakları etkili kullanma" teması altında şu şekilde yer vermiştir:

"Gözlem kayıt kartlar oluşturulur. evde, okulda ve sosyal yaşamda kaynakları etkili kullanma ve israf etme ile ilgili gözlemlerin öğrenciler tarafindan kayıt altına alınması istenir. sonrasında sınıfta kartlar okunarak elde edilen sonuçlarla ilgili çözüm önerileri bulunur (P.52)"

Bir öğretmen adayı tasarladığı ders planında girişimciliğe "Maliyet Analizi" teması altında şu şekilde yer vermiştir:

Öğrencilerin önce istek ve ihtiyaçlarm listelemeleri; sonra da eldeki kaynaklara göre bütçe planlaması yapmalan istenir (P. 51)"

Bir öğretmen adayı tasarladığı ders planında girişimciliğe "Sorumluluk Alma" teması altında şu şekilde yer vermiştir:

"Organ bağışının önemini yakın çevreye duyurmaya yönelik olarak öğrencilerin afiş hazırlamaları; ailelerini, mahallelerindeki kişileri, esnafları bu afişlerle bilgilendirmeleri sağlanır (P.47)"

Bir öğretmen adayı tasarladığı hazırladığı ders planında girişimciliğe "Planlama" teması altında şu şekilde yer vermiştir:

"Olasi bir depremde kendine lazım olacak malzemelerin listesini yaparak deprem çantası hazırlamaları ve evlerin deprem tahliye planın aileleriyle birlikte hazırlayarak evlerinin uygun bir yerine asmalarn istenir (P.35)"

Bir öğretmen adayı tasarladığı ders planında girişimciliğe "İkna ve İletişim" teması altında şu şekilde yer vermiştir:

“Teknolojinin yanlış kullanımına bir örnek olarak dijital oyunlar ve zararları üzerine tartışılır. sokak röportajları ile geleneksel çocuk oyunları ile ilgili bilgi toplamaları istenir (P. 38)"

Bir öğretmen adayı tasarladı̆̆ı ders planında girişimciliğe "Pazarlama Stratejileri" teması altında şu şekilde yer vermiştir:

"Öğrencilere günlük yaşamlarında gözlemledikleri bir sorunu çözmek üzere bir ürün tasarlamalarına yönelik olarak icat kağıtları dağıtılır. Tasarımı biten öğrencilerin ürünlerini pazarlamak için reklam filmi gibi ya da konuşma gibi çalışmalar yapmaları istenir (P.31)"

Bir öğretmen adayı tasarladığı ders planında girişimciliğe "Rekabetçi Düşünme" teması altında şu şekilde yer vermiştir:

"Öğrencilere yeni çıkan her ürünü ihtiyacı olmadiğı halde almak isteyen Ali'nin yaşadıkları bir örnek olay biçiminde sunulur. sonra şirketlerin reklamlarla insanları 
ne şekilde tüketici haline getirdiği; birbirleriyle rekabet ederken ne tür stratejiler kullandıkları örnek reklamlar üzerinden tartışılır (P.31)"

Bir öğretmen adayı girişimcilik konularına yönelik tasarladığı Fen Bilimleri dersi planında "Fırsatları fark etme" boyutu ile şu şekilde yer vermiştir:

"Öğrencilere eskiden kullandığımız aletlerin yetersiz kaldı̆̆ını, şimdiki teknolojik aletlerin ise insan kullanımından dolayı oldukça vaktimizi aldığı, tüm bu olumsuz özelliklerin ortadan kaldırıldı̆̆ı herkesin hayatını kolaylaştırabilecek bir aletin olup olmadiğı sorulur. daha sonra örnek niteliğinde Steve Jobs, Bill Gates gibi bilim insanlarının hayat hikayelerine değinmek amacıyla bir video izletilir (P3)"

Bir öğretmen adayı girişimcilik konularına yönelik tasarladığı Fen Bilimleri dersi planında "Yenilikçilik ve yaratıcılık (iş fikri belirleme)" boyutu ile şu şekilde yer vermiştir:

"Öğrencilere A4 kağıtları dağıtılarak hayalindeki teknolojik aydınlanma aracın tasarlaması istenir, ayrıca öğrencinin tasarladı̆̆ı aracı sinıfa detaylı bir şekilde tanıtmast istenir (P79)"

Bir öğretmen adayı girişimcilik konularına yönelik tasarladığ dersi planında "Sorumluluk Alma" boyutu ile şu şekilde yer vermiştir:

"Öğrencilerden haftaya gelirken bir diyetisyen hekimle görüşüp paketli gıdalar, obezite hakkında röportaj yapmaları bu röportajı kayıt altına almalarn ve sinıfta arkadaşlarına sunmalar istenir. Ayrıca öğrencilerden paketlenmiş ve donmuş gıdaların zararları, obezite, tarihi geçmiş gıdalar, hakkında pano ve sunum hazırlamalar istenir (P91)"

Bir öğretmen adayı girişimcilik konularına yönelik tasarladığı Fen Bilimleri dersi planında "İkna ve İletişim" boyutu ile şu şekilde yer vermiştir:

"Öğrencilerden ses kirliliğine yönelik olası çözüm önerileri istenir, ayrnca buldukları çözüm önerisini resimlerle ve yazılarla afiş şeklinde açıklamalarn istenir (P84)"

"Öğrencilerden toplumun teknolojik aletlerin kullanım kılavuzunu uyarnlar yeterli bulup bulmadıkları hakkında bir sokak röportajı yaptırılır (P7)"

Bir öğretmen adayı girişimcilik konularına yönelik tasarladığı Fen Bilimleri dersi planında "Pazarlama stratejileri" boyutu ile şu şekilde yer vermiştir:

"Öğrencilerden hayal güçlerini kullanarak hayatımızı kolaylaştırabilecek yeni bir icat düşünmeleri istenir. Konuyla ilgili düşüncelerine yönelik afiş, röportaj vb hazırlamalarn istenir. Daha sonra düşündüklerini hayata geçirip pazarlamalarına olanak sağlanır (P21)"

Bir öğretmen adayı girişimcilik konularına yönelik tasarladığı Fen Bilimleri dersi planında "Farklı alanlara uyarlama" boyutu ile şu şekilde yer vermiştir:

"Öğrencilerden mıknatısların yeni kullanım alanları konusunda fikirlerini açıklamaları ayrıca günlük hayatta mıknatısların özellikle nerelerde kullanabileceğine yönelik araştırma yapmalar istenir. Öğrencilerden miknatısın farklı alanlarda kullanılmasına yönelik ne gibi önerilerinin olduğu istenir (P87)" 
"Öğrenciler mıknatısı günlük hayatımıza uyarlarlar ve öğrenmiş olduğu kullanım alanlarından yola çıkarak yeni kullanım alanların düşünüp fikir üretebilirler (P106)"

\section{Tartışma, Sonuç ve Öneriler}

Nicel verilerden elde edilen sonuçlar, sınıf öğretmen adaylarının sosyo-bilimsel konulara yönelik tutum puanlarının "sık sık" kategorisinde olduğu görülmüş̧tür. Bu sonuç, sınıf öğretmeni adaylarının sosyo-bilimsel konulara yönelik tutumlarının yüksek olduğunun bir göstergesi olabilir. Yolagiden (2017) tarafından yapılan çalışmada, "Sosyo-bilimsel Konulara Yönelik Tutum Ölçeğiı"nin tümünden ve iki alt boyutundan aldıkları ortalama puanların "sık sık" kategorisinde olduğu, bir alt boyutundan (sosyo-bilimsel konulara yönelik kayg1 alt boyutu) ise "bazen" kategorisinde olduğu belirtilmiştir. Atalay ve Çaycı (2017) tarafından yapılan çalışmada, sınıf öğretmeni adaylarının sosyo-bilimsel konular hakkındaki tutumlarının "orta düzeyde" olduğu belirlenmiştir. Benzer şekilde, sınıf öğretmeni adaylarının "Üniversite Öğrencilerine Yönelik Girişimcilik Ölçeği"nden aldıkları puanın "katılıyorum" kategorisinde olduğu görülmüştür. Bu sonuç, sınıf öğretmeni adaylarının yüksek girişimcilik düzeyine sahip olduğunu göstermektedir. Karademir, Balbağ ve Çemlek (2018) öğretmen adaylarının girişimcilik becerilerini çeşitli değiş̧kenler açısından incelemişlerdir. Araştırma sonucunda sınıf öğretmeni adaylarının girişimcilik puanlarının diğer öğretmen adaylarından (fen bilgisi, sosyal bilgiler, ilköğretim matematik, PDR, zihinsel engelliler öğretmenliği) daha yüksek olduğu görülmüştür. Mevcut araştırmada da sınıf öğretmeni adaylarının girişimcilik becerisi düzeylerinin yüksek olduğu belirlenmiştir.

Sınıf öğretmeni adaylarının girişimcilik puanları ve sosyo-bilimsel konulara yönelik tutum puanları arasında orta düzeyde pozitif bir ilişkinin olduğu görülmüştür. 2018 fen bilimleri dersi öğretim programında sosyo-bilimsel konular ve girişimcilik gibi kavramların ön plana çıktığı görülmektedir. Bu bağlamda iki kavram arasındaki pozitif ilişkinin araştırma konusu olarak seçilmesi ve aralarındaki ilişkinin incelenmesi önemli görülmektedir.

$\mathrm{Bu}$ araştırmada yapılan doküman analizinde ders planlarında belirtilen kazanımlar çerçevesinde yürütülen etkinliklerin ölçütler takımında tema olarak ele alınan sosyo-bilimsel konuları ne ölçüde içerdiği incelenmiştir. Bu inceleme sonucunda, sınıf öğretmeni adaylarının tasarladıkları ders planlarında sosyo-bilimsel konuların bir kısmına değindikleri, bir kısmına ise hiç değinmedikleri ortaya çıkmıştır. Örneğin, canlı çeşitliliği, salgın hastalıklar, uzay araştırmaları gibi sosyobilimsel konulara hiç değinilmemiştir. Benzer biçimde, Yenilmez Türkoğlu ve Öztürk (2019) tarafından yapılan çalışmada, öğretmen adaylarının nükleer santraller gibi bazı sosyo-bilimsel konularda daha detaylı zihinsel modeller sergilerken, şeker yüklemesi gibi diğer bazı konularda ise açık ve net zihinsel modeller sergileyemedikleri belirtilmiştir.

Yapılan bu araştırmada öğretmen adayları tarafından hazırlanan ders planlarında ele alınan sosyo-bilimsel konulardan birinin GDO olduğu ve bu bağlamda özellikle dondurulmuş gıdalar ve konservelere değindikleri ortaya çıkmıştır. Benzer biçimde Öztürk ve Eş (2017) tarafından yapılan çalışmada öğretmen adaylarının sosyo-bilimsel konular hakkında genel anlamda bilgi sahibi oldukları ancak bu konulara yaklaşımları ile ilgili farklılıklarının olduğu, örneğin öğretmen 
adaylarının birçoğunun GDO konusunda olumsuz yaklaşım sergiledikleri belirtilmiştir.

Girişimcilik becerisine pek çok ülkede öğretim programlarında farklı biçimlerde yer verildiği görülmektedir. Finlandiya öğretim programlarında önemli bir yeterlilik alanı; Hırvatistan'da eğitim reformlarında ele alınan bir bileşen; Avusturya, Macaristan, Portekiz, ve İsveç'te temaların içinde gömülü biçimde yer verilen bir beceri; Belçika, Hollanda, İsveç ve Finlandiya'da ulusal düzeyde bir programın veya stratejinin bir parçası olarak gerçekleştirilen eylem biçiminde girişimciliğe yer verildiği görülmektedir (Curth, 2011).

Öğretmen adaylarının ders planlarında sosyo-bilimsel konulara yer verdikleri uygulamalar incelendiğinde afiş ve broşür hazırlama, sokak röportajları yapma, çevre eylemleri ve pankart hazırlama, medya ürünlerinden yararlanma, tartışma gibi uygulamalar tasarladıkları görülmektedir. Bu etkinliklerin deneyim kazanmaya, ilk elden bilgi toplama ve uygulamaya dönük etkinlikler olduğu düşünüldüğünde Sadler, Chambers ve Zeidler (2004)'in ifade ettiği gibi öğrencilerin sosyo-bilimsel konulardaki görüşlerinin, kişisel deneyimlerle ilgili olduğu görüşüne benzer ders planları tasarladıkları söylenebilir.

Öğrenciler sosyo-bilimsel konuları içeren derslerde fen konularının ve sosyal konuların ortak yanlarını fark edebilmektedirler ve bu sosyo-bilimsel konular hakkında fikir yürütebilmektedirler (Cansız, 2014). Bu durum yapılan bu araştırmada da benzer biçimde öğretmen adaylarının hem Sosyal Bilgiler Dersi Öğretim Programı'nda hem Fen Bilimleri dersi öğretim programında yer alan kazanımları kullanarak ders plânlarında sosyo-bilimsel konulara yer vermeleri ile ilişkilendirilebilir. Bu bağlamda, her iki dersin öğretim programına göre hazırlanan ders planlarında ortak olarak yer verilen sosyo-bilimsel konular, kirlilik, beslenme ve obezite ile doğal kaynakları koruma olarak ortaya çıkmıştır.

Öğretmen adayları girişimcilik boyutuna ilişkin olarak: Proaktiflik (Öncü Olma), fırsatları fark etme, yenilikçilik ve yaratıcılık, kaynakları etkili kullanma, maliyet analizi, sorumluluk alma, yönetsel yetkinlik, planlama, ikna ve iletişim, pazarlama stratejileri, rekabetçi düşünme, farklı alanlara uyarlama temalarının tümüne ders planlarında yer vermişlerdir. Öğretmen adaylarının sosyal bilgiler dersinde girişimciliği ilişkilendirdikleri kazanımlara ait temalar göz önünde bulundurulduğunda programda yer alan sekiz öğrenme alanından yedisi ile girişimciliği ilişkilendirdikleri görülmektedir. Öğretmen adaylarının fen bilimleri dersinde girişimciliği ilişkilendirdikleri kazanımlara ait temalar incelendiğinde ise öğretmen adaylarının girişimciliği programda yer alan iki öğrenme alanını kullanarak (Canlılar ve Yaşam ile Fiziksel Olaylar) ele aldıkları ortaya çıkmıştır.

Elde edilen sonuçlar ışığında aşağıdaki önerilere yer verilmiştir:

- $\quad \mathrm{Bu}$ araştırmada öğretmen adayları tarafından ders planlarında sosyobilimsel konuların bir kısmına hiç değinilmediği ortaya çıkmıştır. Bu bağlamda sosyo-bilimsel konuların farklı disiplinlerin öğretiminde geniş bir şekilde ele alınması ve öğretmen adayları tarafından kullanımının sağlanması için çalışmalar yapilmalidir.

- Özel öğretim yöntemleri ya da alan öğretimi derslerinde girişimciliğin farklı alt boyutlarına vurgu yapacak ders planları öğretmen adayları tarafından hazırlanmalıdır. 
- $\quad$ Fen öğretimi ve sosyal bilgiler öğretimi gibi alan eğitimi derslerinde bütüncül bir bakış açısı kazandırabilmek, öğretmen adaylarına yeterlik kazandırabilmek için sosyo-bilimsel konuların ve girişimcilik gibi becerilerin ne şekilde işe koşulabileğine yönelik uygulamalar yapılabilir.

- Karma yöntem ile yürütülen bu araştırma gibi farklı yöntemler kullanılarak yeni araştırmalar yürütülebilir.

- Uygulayıcıların kaynak olarak kullanabilmeleri için bu tür disiplinler arası çalışmalar için uygulama örnekleri geliştirilebilir.

- Farklı çalışma grupları ile bu tür araştırmalar gerçekleştirilebilir.

\section{Kaynakça}

A ğca, V., ve Kurt, N. (2007). İç girişimcilik ve temel belirleyicileri: kavramsal bir çerçeve. Erciyes Üniversitesi İktisadi ve İdari Bilimler Fakültesi Dergisi, 29, 83112.

Atalay, N., ve Çayc1, B. (2017). Sınıf öğretmeni adaylarının sosyo-bilimsel konular hakkındaki görüş ve tutumlarının farklı değişkenlere göre incelenmesi. Eskişehir Osmangazi Üniversitesi Türk Dünyası Uygulama ve Araştırma Merkezi ESTÜDAM Ĕ̆itim Dergisi, 2(2), 35-45.

Cansız, N. (2014). Fen bilgisi öğretmen adaylarının sosyo-bilimsel konularda muhakeme yeteneklerinin geliştirilmesi (Yayımlanmamış doktora tezi). Orta Doğu Teknik Üniversitesi Eğitim Bilimleri Enstitüsü, Ankara

Creswell, J. W., ve Plano, C.V.L. (2014). Karma yöntem araştırmaları tasarımı ve yürütülmesi, (Çev: Yüksel Dede ve Selçuk Beşir Demir), Ankara: Anı Yayınc1lik.

Çavuş, F. M.,ve Pekkan, N. Ü. (2017). Algılanan sosyal desteğin sosyal girişimciliğe etkisi: üniversite öğrencileri üzerinde bir araştırma. Business and Economics Research Journal, 8(3), 519-532. https:// doi.org/10.20409/berj.2017.64

Eastwood, J. L., Sadler, T. D., Zeidler, D. L., Lewis, A., Amiri, L., and Applebaum, S. (2012). Contextualizing nature of science instruction in socioscientific issues. International Journal of Science Education, 34(15), 2289-2315. https:/ / doi.org/10.1080/09500693.2012.667582

Evren Yapıcıoğlu, A., ve Kaptan, F. (2017). Sosyo-bilimsel konu temelli öğretim yaklaşımı uygulamalarının etkililiğgine yönelik bir karma yöntem çalışması. Eğitim ve Bilim, 42 (192), 113-137.

Evren Yapıcıoğlu, A., ve Kaptan, F. (2018). Sosyo-bilimsel durum temelli öğretim yaklaşımının argümantasyon becerilerinin gelişimine katkısı: bir karma yöntem araştırması. Ondokuz Mayıs Üniversitesi Ĕ̆itim Fakültesi Dergisi, 1(37), 39-61.

Curth, A. (2011). Mapping of teachers' preparation for entrepreneurship education. https://www.ab.gov.tr/files/ardb/evt/1_avrupa_birligi/1_9_politikalar/1 _9_4_egitim_politikasi/mapping_en.pdf adresinden indirilmiştir.

Hodson, D. (2006). Why we should prioritize learning about science. Canadian Journal of Math, Science \& Technology Education, 6(3), 293-311. https://doi.org/10.1080/14926150609556703

Karademir, E., Balbă̆, M. Z., ve Çemlek, F. (2018). Öğretmen adaylarının girişimcilik düzeylerinin bazı değişkenlere göre incelenmesi. Milli Ĕ̆itim, 220, 177-200. 
Kılıç Kırılmaz, S. (2014). Sosyal girişimcilik boyutlarına kuramsal bir bakış. Journal of Economics and Management Research, 3(2), 55-74.

Lee, H., Abd-El-Khalick, F., and Choi, K. (2006). Korean science teachers' perceptions of the introduction of socio-scientific issues into the science curriculum. Canadian Journal of Math, Science E Technology Education, 6(2), 97-117. https://doi.org/10.1080/14926150609556691

McMillan, J. H., and Schumacher, S. (2010). Research in education: evidence-based inquiry. (7th ed.). Boston, MA: Pearson.

Merriam, S. (1998). Qualitative research and case study applications in education. Revised and expanded from case study research in education. USA: JB Printing.

Miles, M. B., and Huberman, A. M. (1994). Qualitative data analysis: An expanded sourcebook (2nd Ed.). Thousand Oaks: Sage Publications.

Milli Eğitim Bakanlığı (MEB). (2005). Fen ve Teknoloji Dersi Öğretim Programı. Ankara: Millî Eğitim Bakanlığ1 Talim ve Terbiye Kurulu Başkanlığ1.

Milli Ĕ̆itim Bakanlı̆̆ı (MEB). (2013). Fen Bilimleri Dersi Öğretim Programı. Ankara: Millî Eğitim Bakanlığı Talim ve Terbiye Kurulu Başkanlığı.

Milli Eğitim Bakanlı̆̆ı (MEB). (2018). Fen Bilimleri Dersi Öğretim Programı. Ankara: Millî Eğitim Bakanlığı Talim ve Terbiye Kurulu Başkanlığ1.

O'Neil, K., and Gibbs, D. (2016). Rethinking green entrepreneurship - Fluid narratives of the green economy. Environment and Planning. 48 (9), 17271749. https:/ / doi.org/10.1177/0308518X16650453

Özden, M. (2016). Bilim Okuryazarlığı İçin Bir Çerçeve: Fen-Teknoloji-Toplum-Çevre, Fen Bilimleri Öğretimi içinde (2. Baskı). Ankara: Anı Yayıncılık.

Öztürk, N., ve Eş, H. (2017). Fen bilimleri öğretmen adaylarının bazı sosyo-bilimsel konulara yaklaşımları ve gerekçeleri. II. International Academic Research Congress. 18-21 Ocak 2017, Alanya-ANTALYA.

Öztürk, S., ve Leblebicioğlu, G. (2015). Sosyo-bilimsel bir konu olan hidroelektrik santraller (HES) hakkında karar verilirken kullanılan irdeleme şekillerinin incelenmesi. Necatibey Eğitim Fakültesi Elektronik Fen ve Matematik Ĕ̆itimi Dergisi, 9(2), 1-33. https:// doi.org/10.17522/nefefmed.88999

Saifan, S. A. (2012). Social Entrepreneurship: Definition and Boundaries. Technology Innovation Management Review. February. (https://timreview.ca/sites/default/files/article_PDF/Saifan_TIM Review_February2012_2.pdf) adresinden alınmıştır.

Sadler, T. D. (2004). Informal reasoning regarding socioscientific issues: A critical review of research. Journal of Research in Science Teaching: The Official Journal of the National Association for Research in Science Teaching, 41(5), 513-536. https://doi.org/10.1002/tea.20009

Sadler, T. D., Chambers, F. W., and Zeidler, D. L. (2004). Student conceptualizations of the nature of science in response to a socioscientific issue. International Journal of Science Education, 26(4), 387- 409. https://doi.org/10.1080/0950069032000119456

Sadler, T. D., and Zeidler, D. L. (2005). Patterns of informal reasoning in the context of socioscientific decision making. Journal of Research in Science Teaching, 42(1), 112-138. https:/ / doi.org/10.1002/tea.20042 
Sadler, T., and Donnelly, L. (2006). Socioscientific argumentation: The effects of content knowledge and morality. International Journal of Science Education, 28(12), 1463-1488. https:/ / doi.org/10.1080/09500690600708717

Sadler, T.D., and Zeidler, D.L. (2009). Scientific literacy, PISA, and socioscientific discourse: Assessment for progressive aims of science education. Journal of Research in Science Teaching, 46(8), 909-921. https://doi.org/10.1002/tea.20327

Şen, E., and Aslan, İ. (2017). Effects of entrepreneur personal characteristics on entrepreneurance tendency. Journal of social and humanities sciences research, 4(15), 1847-1855. https:/ / doi.org/10.26450/jshsr.284

Sönmez, A. (2015). Fen bilimleri öğretmenlerinin epistemolojik inanç sistemleri ve sosyo-bilimsel konular hakkında yaptıkları öğretimler arasındaki ilişkilerin belirlenmesi (Doktora tezi). Abant İzzet Baysal Üniversitesi Eğitim Bilimleri Enstitüsü, Bolu.

Tezel, Ö., ve Günister, B. (2018). Sosyo-bilimsel konu temelli fen öğretimi üzerine Türkiye' de yapılan çalışmalardan bir derleme. Eskişehir Osmangazi Üniversitesi Türk Dünyası Uygulama ve Araştırma merkezi (ESTÜDAM) Eğitim Dergisi, 3(1), 42-60.

Topçu, M. S. (2010). Development of attitudes towards socioscientific 1ssues scale for undergraduate students. Evaluation \& Research in Education, 23(1), 51-67. https://doi.org/10.1080/09500791003628187

Topçu, M. S., ve Atabey, N. (2017). Sosyo-bilimsel konu içerikli alan gezilerinin ilköğretim öğrencilerinin argümantasyon nitelikleri üzerine etkisi. Bartın Üniversitesi Ĕ̆itim Fakültesi Dergisi, 6(1), 68-84. https://doi.org/10.14686/buefad.263541

Topçu, M.S., Muğaloğlu, E.Z., ve Güven, D. (2014). Fen Eğitiminde Sosyo-bilimsel Konular: Türkiye Örneği. Kuram ve Uygulamada Eğitim Bilimleri, 14(6), 1-22.

Topkaya, Ö. (2013). Tarihsel süreçte girişimcilik teorisi: girişimciliğin ekonomik büyüme ve istihdam boyutu. Journal of Entrepreneurship and Development, 8(1), 29-54.

Türkmen, H., Pekmez, E., ve Sağlam, M. (2017). Fen Bilgisi Öğretmen Adaylarının Sosyo-Bilimsel Konular Hakkındaki Düşünceleri. Ege Eğitim Dergisi, 2(18), 448-475. https:/ / doi.org/10.12984/egeefd.295597

Yıldırım, A.,ve Şimşek, H. (2013). Sosyal bilimlerde nitel araştırma yöntemleri (9. Baskı). Ankara : Seçkin Yayıncılık.

Yılmaz, E., ve Sünbül, A. M. (2009). Üniversite öğrencilerine yönelik girişimcilik ölçeğinin geliştirilmesi. Selçuk Üniversitesi Sosyal Bilimler Enstitüsü Dergisi. 21, 195-203.

Yenilmez Türkoğlu, A. ,ve Öztürk, N. (2019). Sosyo-bilimsel konulara ilişkin fen bilgisi öğretmen adaylarının zihinsel modelleri. Başkent University Journal of Education, 6(1),127-137.

Yolagiden, C. (2017). Öğretmen adaylarının fen öğrenme becerisi, fen okuryazarlı̆̆ı ve sosyo-bilimsel konulara yönelik tutumları arasındaki ilişkinin araştırılması. (Yayınlanmamış yüksek lisans tezi). Kahramanmaraş Sütçü İmam Üniversitesi Fen Bilimleri Enstitüsü, Kahramanmaraş. 


\section{Summary}

\section{Introduction}

In the researches, it was found out that the level of knowledge of teachers and preservice primary school teachers on socio-scientific issues and their teaching is not at the desired level and that teachers do not give much space to such subjects in their courses or they pass the course through unplanned discussions. There is no study that examines the relationship between the two or the socio-scientific issues that are conducted with teachers/pre-service primary school teachers and entrepreneurship together. This study is designed as mixed method research and it is important in terms of addressing socio-scientific issues and entrepreneurship and seeing how teacher candidates place socio-scientific issues and entrepreneurship in their lesson plans.

\section{Method}

The aim of this study is to determine the attitudes of pre-service primary school teachers towards socio-scientific issues and their level of entrepreneurship and to reveal how they place socio-scientific issues and entrepreneurship in their lesson plans. In current study, mixed method research was used. The participants of the study consisted of 88 pre-service primary school teachers. Participants were selected according to the criterion sampling method. "Attitude Scale for Socio-Scientific Issues" and "Entrepreneurship Scale for University Students" were used as data collection tools and "Lesson Plans" were used as documents.

\section{Results}

According to the results obtained from the quantitative data, it was observed that the average attitude scores of the pre-service primary school teachers towards socioscientific issues were "often". Similarly, the average scores of entrepreneurship were "agree". In addition, there was a moderate positive relationship between the attitudes of pre-service primary school teachers towards socio-scientific issues and their entrepreneurship. In addition, according to the results obtained from the qualitative data, it was found that the lesson plans prepared by the pre-service primary school teachers included all the dimensions of entrepreneurship; and some of the socio-scientific issues were not mentioned. Especially in the context of social studies lesson, it has been revealed that they don't have problems in handling entrepreneurship skills. The socio-scientific issues, which are included in the lesson plans prepared according to both science and social studies curriculum, are determined as pollution, nutrition and obesity and conservation of natural resources. When the lesson plans are examined, it is seen that they design implementations such as preparing posters and brochures, doing street interviews, preparing environmental actions and banners, utilizing media products, and discussing for socio-scientific issues.

\section{Discussion}

The results obtained from the current study, the quantitative data showed that the pre-service teachers' attitude scores towards socio-scientific subjects were in the "frequently" category. In the study conducted by Yolagiden (2017), it was stated that the average scores they received from the "Attitude Scale towards Socio-scientific Issues" and their two sub-dimensions were in the "frequent" category. In the study 
conducted by Atalay and Çaycı (2017), it has been determined that the attitudes of elementary teacher candidates on socio-scientific issues are "at an intermediate level".

In current study, it was found out that pre-service primary school teachers mentioned some socio-scientific issues and all aspects of entrepreneurship in their lesson plans. Similarly, in the study conducted by Yenilmez Türkoğlu and Öztürk (2019), it was stated that pre-service primary school teachers could not demonstrate clear mental models on some socio-scientific issues. Karademir, Balbağ and Çemlek (2018) showed that the entrepreneurship scores of the pre-service teachers were higher than the others. In this study, the entrepreneurial skills of pre-service primary school teachers are high level.

\section{Pedagogical Implications}

- In order to gain a holistic perspective in field education courses such as science teaching and social studies teaching, and to gain competence for prospective teachers in interdisciplinary applications, applications can be made in terms of socio-scientific issues and skills such as entrepreneurship.

- New research can be carried out using different methods such as a mixed research.

\section{Araştırmanın Etik İzinleri}

Yapılan bu çalışmada "Yükseköğretim Kurumları Bilimsel Araştırma ve Yayın Etiği Yönergesi" kapsamında uyulması belirtilen tüm kurallara uyulmuştur. Yönergenin ikinci bölümü olan “Bilimsel Araştırma ve Yayın Etiğine Aykırı Eylemler” başlı̆̆ı altında belirtilen eylemlerden hiçbiri gerçekleştirilmemiştir.

Etik kurul izin bilgileri

Etik değerlendirmeyi yapan kurul ad1 = Afyon Kocatepe Üniversitesi Sosyal ve Beşeri Bilimleri Bilimsel Araştırma ve Yayın Etiği Kurulu

Etik değerlendirme kararının tarihi=20.03.2020

Etik değerlendirme belgesi sayı numarası $=02$

\section{Authors' Biodata/ Yazar Bilgileri}

Bülent AYDOĞDU, Afyon Kocatepe Üniversitesi Eğitim Fakültesi Fen Bilimleri Eğitimi Bölümü'nde Doçent Doktor olarak görev yapmaktadır. Fen öğretimi, bilimsel araştırma yöntemleri, fen eğitiminde materyal tasarımı, öğrenmeyi öğrenme, nicel ve nitel araştırma yöntemleri gibi lisans ve yüksek lisans düzeyinde dersler vermektedir. Araştırma ilgi alanları arasında fen eğitimi, STEM, STEAM, E-STEM, fen laboratuvarı, bilim süreç becerileri, argümantasyon temelli öğrenme, öğretmen eğitimi ve sorgulamaya dayalı öğrenme yer almaktadır. Ayrıca Türkiye Bilimsel ve Teknolojik Araştırma Kurumu (TÜBİTAK-No. 218B452) tarafından desteklenen ESTEM adlı bir projesi bulunmaktadır.

Bulent Aydogdu is currently Associate Professor Doctor at the Department of Science Education, Faculty of Education, Afyon Kocatepe University, Turkey. He taught undergraduate- and graduate-level courses, such as science teaching, scientific research methods, material design in science education, learning to learn, quantitative and qualitative research methods. His research interests include science education, STEM, STEAM, E-STEM, science laboratory, science process skills, 
argumentation-based learning, teacher education, and inquiry-based learning. Furthermore, he has a project named E-STEM granted by the Scientific and Technological Research Council of Turkey (TUBITAK-No. 218B452).

Tuğba SELANİK AY Afyon Kocatepe Üniversitesi Eğitim Fakültesi Temel Eğitim Bölümü'nde Doçent Doktor olarak görev yapmaktadır. Sosyal bilgiler öğretimi, sosyal becerileri öğretimi, değerler eğitimi, nitel araştırma yöntemleri, sosyal bilgiler öğretiminde yeni yaklaşımlar, sosyal bilgiler ders kitapları ve programları, ilköğretim ders kitaplarını inceleme gibi hem lisans hem de lisansüstü düzeyde dersleri sürdürmeye devam etmektedir. Çalışma alanı sosyal bilgiler eğitimi, girişimcilik, hukuk okuryazarlığı, değerler eğitimi ve öğretmen yetiştirmedir.

Tugba Selanik Ay is currently Associate Professor Doctor of Primary Education Department, Faculty of Education, Afyon Kocatepe University, Turkey. She taught courses both undergraduate and graduate level such as teaching social studies, teaching social skills, values education, qualitative research methods, new approaches for teaching social studies, social studies course books and pragrammes and investigating elementary course books. Her studying area is teaching social studies, entrepreurship, legal literacy, values education and teacher training.

Nil DUBAN Afyon Kocatepe Üniversitesi Eğitim Fakültesi İlköğretim Bölümü'nde profesör doktor olarak görev yapmaktadır. Fen öğretimi, bilimsel araştırma yöntemleri, ilkokulda temel fen bilimleri, ilkokul programları, ilköğretim fen öğretimi, öğrenmeyi öğrenme, nitel araştırma yöntemleri, eğitimde karma yöntem araştırmaları gibi lisans ve lisans üstü düzeyde dersler vermektedir. Araştırma alanları arasında ilköğretim fen bilgisi eğitimi, STEM, STEAM, sorgulamaya dayalı öğrenme bulunmaktadır.

Nil Duban is currently Professor at the Department of Primary Education, Faculty of Education, Afyon Kocatepe University, Turkey. She taught undergraduate- and graduate-level courses, such as science teaching, scientific research methods, basic science at primary schools, primary school Curriculum, primary science teaching, learning to learn, qualitative research methods, mixed method research in education. Her research interests include primary science education, STEM, STEAM, inquirybased learning. 